Egyptian Journal of Aquatic Biology \& Fisheries

Zoology Department, Faculty of Science,

Ain Shams University, Cairo, Egypt.

ISSN $1110-6131$

Vol. 23(5): 393 - 403 (2019)

www.ejabf.journals.ekb.eg

\title{
Environmental Hazardous Optimization of Chlorine Disinfectant by-products of Drinking Water: Plants and Distribution System "Case Study"
}

\author{
Fathy M. Mohamed ${ }^{1}$; Faten Nasr El-Deen $^{2}$ and Mohamed H. Abdo ${ }^{3}$ \\ 1- Faculty of Earth Sciences, Beni-Suef University, Beni-Suef city, Egypt \\ 2- Qena company for Water and Wastewater, Egypt. \\ 3- National Institute of Oceanography and Fisheries, Ministry of Scientific Research, Egypt. \\ * Corresponding author: fathy1973@esc.bsu.edu.eg
}

\begin{abstract}
ARTICLE INFO
Article History:

Received: Oct. 19, 2019

Accepted: Nov. 28, 2019

Online: Dec. 2019
\end{abstract}

Keywords:

Trihalomethanes

Chlorine

Disinfection

By-Products

Pathogens

\begin{abstract}
Trihalomethanes (THMS) are chemicals that are formed when naturally occurring organic materials combine with free chlorine as disinfection byproducts. In spite of the fact that there is a peril of utilizing THMs in chlorinated drinking water, the health dangers of un-disinfected water is much greater. Therefore, this study concerned with lowering chlorine dose to amount adequate to kill waterborne pathogen with low concentration of THMs compound formation. The analysis program was conducted in Qena district at 5 fixed points comprised Salhyia plant outlet and four sites represented beginnings, middle and end of the plant network to determine the presence of chlorine disinfection by-products in treated water with respect to the disinfection process. So, chlorine dose, THMs compounds concentration, temperatures and bacteriological counts were measured along three months. The results showed that when the chlorine dose reduced gradually to $4 \mathrm{mg}$ $\mathrm{L}^{-1}$, formation of chloroform, bromoform, dichlorobromomethane and total THM compounds in the plant outlet decreased gradually and reached to its least concentration $\left(6.2,3.3,0.0,10.9 \mu \mathrm{g} \mathrm{L}^{-1}\right.$ respectively) and inhibited in some cases. This reduction in THM compound formation was also directly proportional to decreasing in temperature ratios. Moreover, bacteriological analysis showed that chlorine reduction did not affect its disinfection efficiency even at the end of the network. So it is recommended to reduce the population's exposure to halogenated organic compounds in drinking water by decreasing the chlorine dose without affecting the disinfection efficiency.
\end{abstract}

\section{INTRODUCTION}

Chlorination has been the major economic and effective drinking water disinfection strategy from microorganisms (Chowdhury and Champagne, 2008; Philip, 2017). Nonetheless, the implementation of the various disinfectant by-products (DBPs), especially chloratinted by-products (DBPs) which are correlated with cancer risks, as well as other acute and chronic effects on human health (IPCS, 2000; Chowdhury and Champagne, 2008; Ahmad and Husain, 2015; Steve et al., 2015; Freeman et al., 2017). The appearance of Disinfection By-Products (DBPs) in drinking water has become a topic of significant scientific regard during the latest decades since 1974; DBPs have been in the spot and discussed (Hrudey et al., 2015). Sundry hundreds of several kinds of DBPs have been distinguished and characterized 
up-to-date and continue being detected (Susan et al., 2002), as more dependable and accurate instrumental analytical techniques are becoming obtainable, which allow their determination at trace levels ( $\mathrm{Li}$ and Mitch 2018, Spyros and Anastasia, 2005). Trihalomethanes are an unfortunate disinfection by-product of water containing natural organic matter (NOM). The four currently regulated THM's are chloroform $\left(\mathrm{CHCl}_{3}\right)$, bromodichlorome thane (BDCM), dibromochloromethane (DBCM), and bromoform $\left(\mathrm{CHBr}_{3}\right)$. These chemicals are formed during disinfection when chlorine oxidizes the natural organic materials (NOM) in the water (Kruger, 2007). DBP formation varies greatly with quality of source water, such as concentrations and properties of NOM (as organic precursors) and levels of bromide (as an inorganic precursor), as well as the chlorination conditions, including chlorine dose, contact time between chlorine and water, temperature and $\mathrm{pH}$ of the reaction solution (Anastasia et al., 2001).

Many studies have been implemented to describe and identify THMs formation and their related health risks (Jinsik et al., 2004, Chowdhury and Champagne, 2008), where the maximum contaminant levels (MCLs) of THM was $0.080 \mathrm{mg} / \mathrm{l}$ according to USEPA (2018), USEPA, 2017a, USEPA, 2017b).

Many studies published in recent years showing the formation and detection of DBPs (Teng et al., 2016; Aleksandra et al., 2017; Yi-Hsueh and William 2017; Haroon et al., 2018).

The essential theme of this study was to detect and locate the drinking water status of El-Salhyia plant outlet and four selected sites represent different sites of its network after reducing the chlorine dosage from 5 to $4 \mathrm{mg} \mathrm{L}^{-1}$ and also to investigate the effect of this application on THM compound formation. Whereas the second objective of this study is optimization of the chlorine dosage required without a formation excess of disinfection byproducts.

\section{MATERIALS AND METHODS}

This study was conducted throughout the 3 months from October to December 2018 in Qena district, Egypt (Fig. 1). The selected plant for this study; El-Salhyia plant (feed Qena city); use free chlorine as a disinfectant. After reducing the chlorine dosage from 5 to $4 \mathrm{mg} \mathrm{L}^{-1}$, THM concentrations were analyzed in five different fixed points comprised Salhyia plant outlet and four different sites represented the beginning, middle and end of the plant network. These are El-Salhyia, El-Konoz, ElSayed, El-Manna and El-Omal sites as shown in Figure (1). For each of the five water sources, THM concentrations, residual chlorine, temperature and bacterial counts were measured before and after reducing chlorine dosage. Free residual chlorine was determined during sampling, according to APHA (2005).

\section{Trihalomethane sampling and analysis}

Samples for trihalomethane analysis were collected in $50 \mathrm{~mL}$ glass bottles in headspace free conditions, capped and placed in the reaction chamber for the designated period. These glass bottles were cleaned and dried in a $105{ }^{\circ} \mathrm{C}$ oven for 1 hour, and then allowed to cool in cold air 30 minutes prior to use. The chemical reducing agent sodium thiosulfate is added to all samples in order to arrest the formation of additional trihalomethanes after sample collection and to eliminate the possibility of free chlorine reacting with impurities in the extraction solvent to form interfering organo-halides. Twenty five $\mathrm{mL}$ from each of the samples were taken for THMs analysis. 


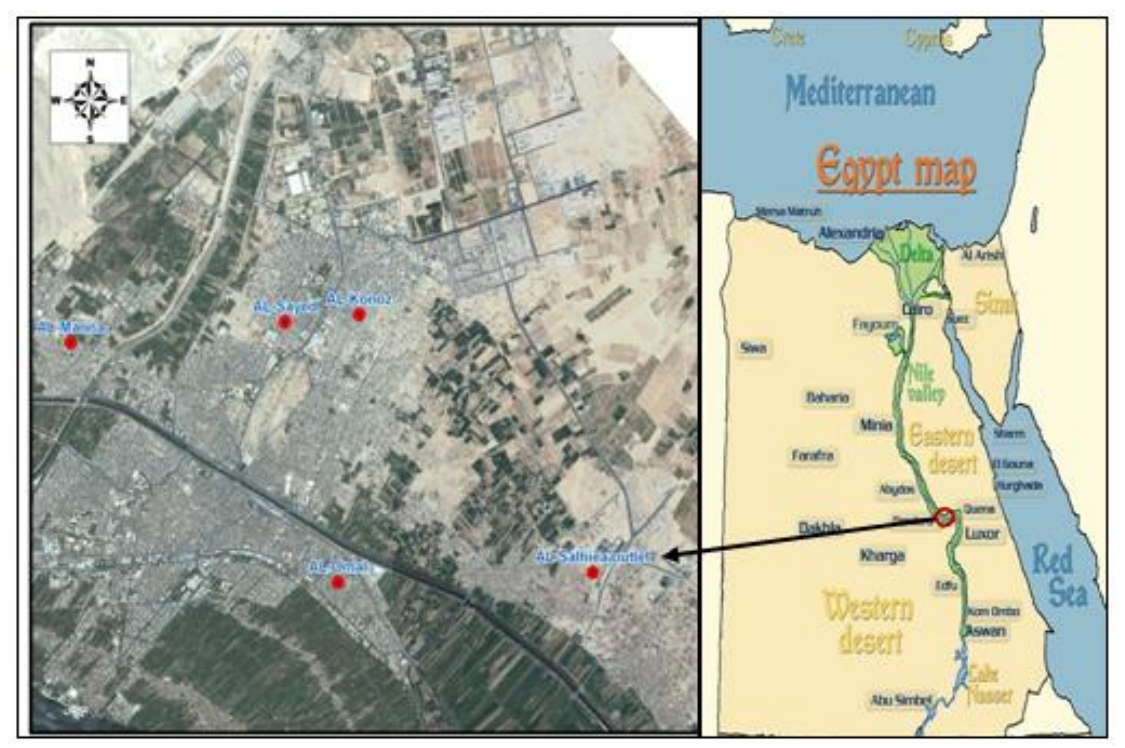

Fig. 1: Egypt map and the study city map including El-Salhyia plant outlet and the different sites of its distribution system.

The THMs were extracted following USEPA 551.1 method (USEPA, 1995). All samples were analyzed within 2 weeks of collection following USEPA method 551.1 (USEPA, 1995). One micro liters of the THMs extracts were analyzed using gas chromatography (GC) equipped with a fused silica column $(0.25 \mathrm{~mm} \times 30 \mathrm{~m})$ and micro electron capture detector ( $\mu$-ECD). The stand-alone methodology to determine trihalomethanes was followed of these analyses. Procedural calibrations were developed using THMs (chloroform, dibromochloromethane, bromoform) standards.

\section{Bacterial Testing}

For bacteria testing, the water samples were analyzed for the total bacterial count at $35^{\circ} \mathrm{C}$ and total bacterial count at $22^{\circ} \mathrm{C}$, total coliform, fecal coliform and fecal Streptococcus bacteria according to APHA (2005). Bacterial analysis was conducted within 24 hours following collection of samples in sterile containers. Total coliform, fecal coliform and fecal Streptococcus bacteria were measured using a portable millipore filtration stand. Samples were diluted appropriately with sterile buffered water, filtered aseptically through a 45-micron filter, placed in a petri-dish with a media soaked pad, and incubated according to APHA (2005).

\section{RESULTS AND DISCUSSION}

The water quality items and disinfection by-products results of drinking water samples from five chosen points in Qena district represent El-Salhyia plant outlet and its distribution system after treatment with two different dosages of chlorine are shown in Figures (2-11). The obtained results show that all the concentration of THMs species was within the range of the decision of the minister of health (458, 2007) for drinking water except the first sample collected. Also, it was found that the most frequently found species of disinfection by-products in the treated water were chloroform and dichlorobromomethane $\left(\mathrm{CHCI}_{2} \mathrm{Br}\right)$. Chloroform was set up to be the most common THM in chlorinated drinking water (Walsh et al., 2008 and Jin et al., 2009). However, other researchers announceed that chloroform exists in the lowest concentration, followed by (bromodichloromethane) BDCM, then dibromochloromethane (DBCM), and lastly bromoform for the distribution of THMs in the water 
containing bromide (Hong et al., 2003 and Whitaker et al., 2003). The reason is that water samples are provided by tap water which was treated by chlorination. Also, it was obvious that decreasing of chlorine dosage had a negative effect on the formation of the disinfection byproducts (Figures 2-6). Hong et al. (2007) showed that the total THM formation positively correlated with chlorination conditions, including chlorine dose and temperature. As shown in Figures (2-6), The reducing of chlorine dosage from 5 to $4 \mathrm{mg} \mathrm{L}^{-1}$ decreased the chloroform concentration from 149.6, 74.4, 43.25, 61.6 and $84.8 \mu \mathrm{g} \mathrm{L}^{-1}$ to $19.9,26.5,26.0,27.6$ and $32.3 \mu \mathrm{g} \mathrm{L}^{-1}$ in plant outlet and the different sites of its distribution system (El-Salhyia, El-Konoz, El-Sayed, El-Omal and El-Manna, respectively).

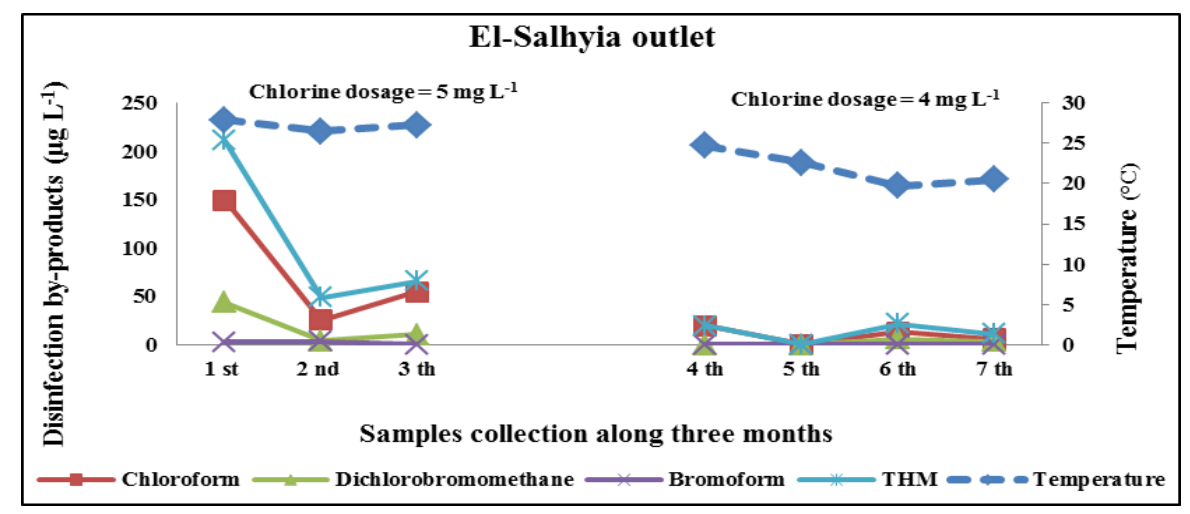

Fig. 2: Effect of temperature and two dosages of chlorine on disinfection by products formation in water samples from El-Salhyia plant outlet.

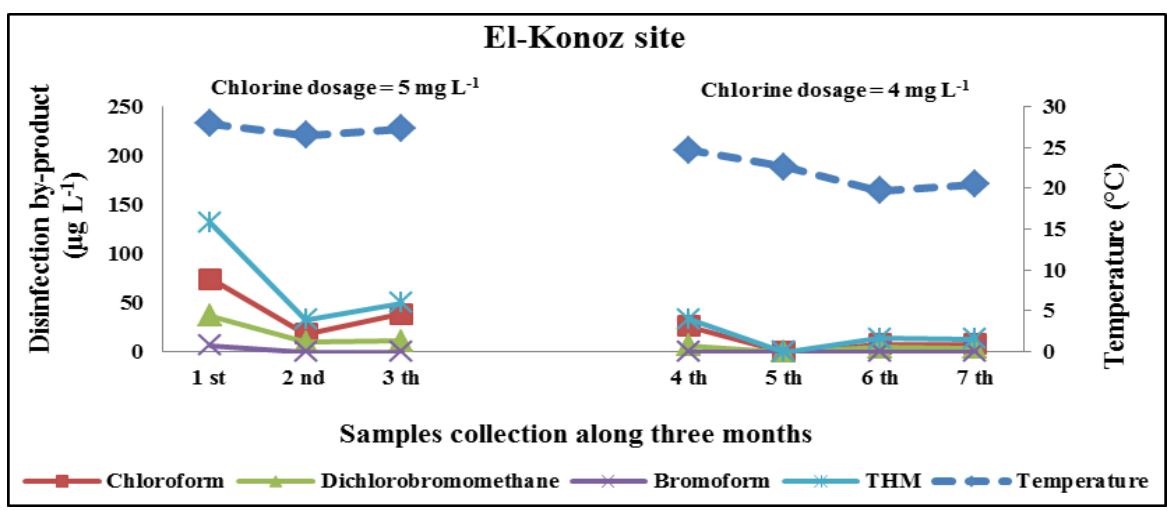

Fig. 3: Effect of temperature and two doses of chlorine on disinfection by products formation in water samples from the first site of the distribution system (El-Konoz site).

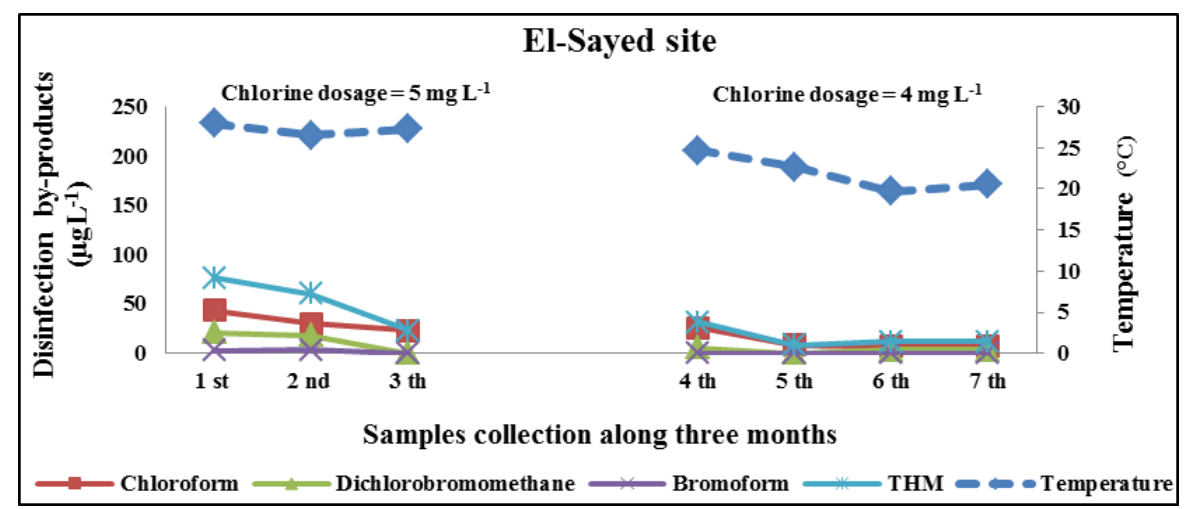

Fig. 4: Effect of temperature and two doses of chlorine on disinfection by products formation in water samples from the second site of the distribution system (El-Sayed site). 


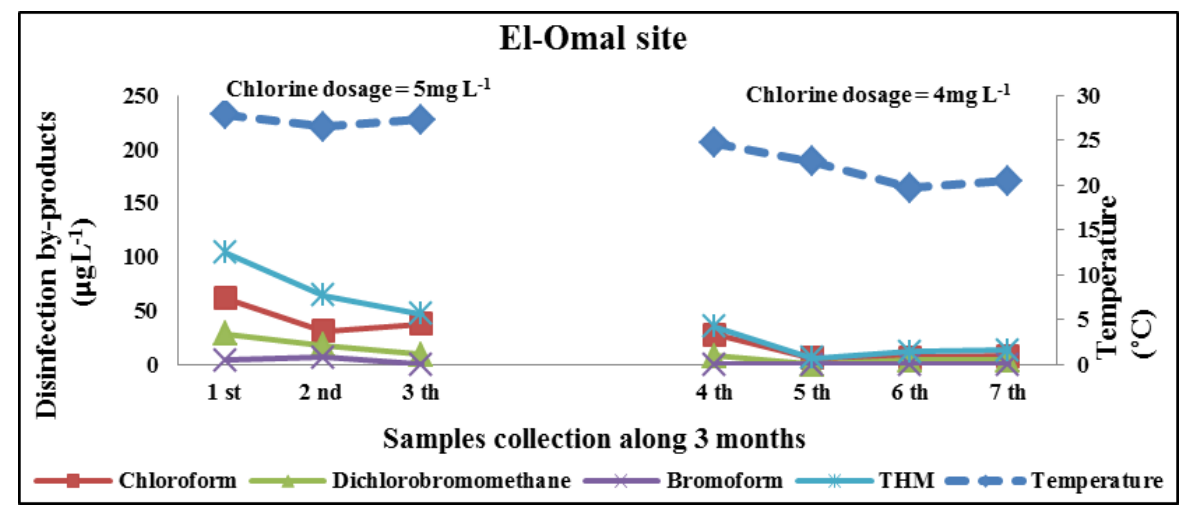

Fig. 5: Effect of temperature and two doses of chlorine on disinfection by products formation in water samples from the third site of the distribution system (El-Omal site).

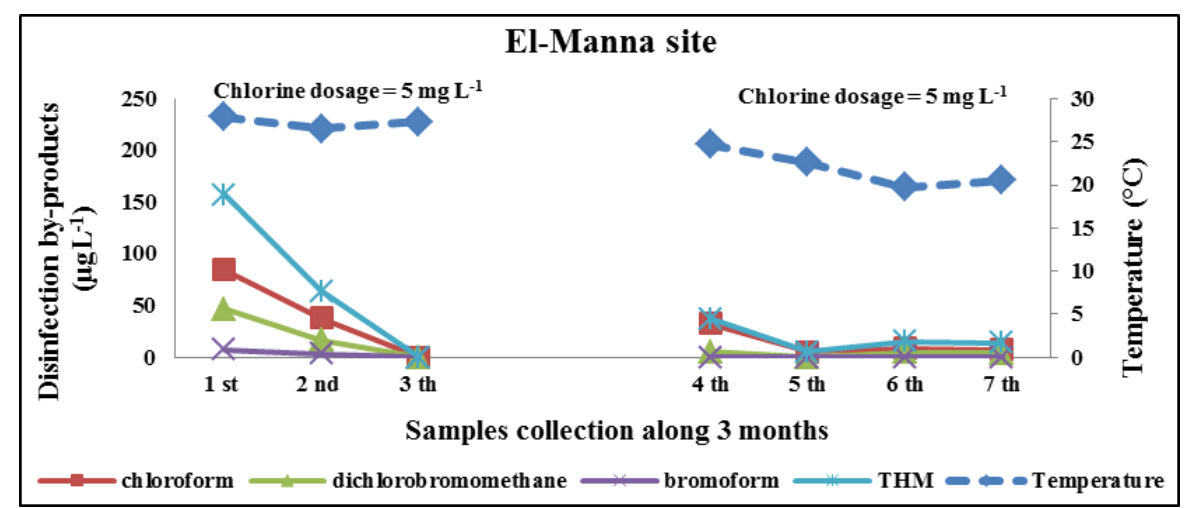

Fig. 6: Effect of temperature and two doses of chlorine on disinfection by products formation in water samples from the fourth site of the distribution system (El-Manna site).

As regards bromoform, its highest concentration was (2.6, 6.2, 3.1, 4.3 and7.3) $\mu \mathrm{g} \mathrm{L}^{-1}$ in water samples of plant outlet and the distribution system sites when the applied chlorine dose was $5 \mathrm{mg} \mathrm{L}^{-1}$. While when the chlorine dosage reduced to $4 \mathrm{mg}$ $\mathrm{L}^{-1}$, its formation was inhibited in all the collected water samples. Also, the dibromochl-oromethane was investigated, where its highest concentrations were 43.9, 36.6, 20.9, 28.5 and $46.4 \mu \mathrm{g} \mathrm{L}^{-1}$ in El-Salhyia, El-Konoz, El-Sayed, El-Omal and ElManna, respectively at the chlorine dosage of $5 \mathrm{mg} \mathrm{L}^{-1}$ and decreased to $(0.0,6.7$, 5.47, 7.72, and 5.23) at chlorine dosage of $4 \mathrm{mg} \mathrm{L}^{-1}$ for the determined site respectively (Figs. 1-5). Consequently, the total trihalomethane concentrations were decreased from $210.8,113.3,76.1,103.8,156.8 \mu \mathrm{g} \mathrm{L}^{-1}$ to $19.9,33.63,31.42,35.27$, $37.41 \mu \mathrm{g} \mathrm{L}^{-1}$ for the selected sites in the same manner (Figs. 1-5). This decrease in THM compound concentration may be related to decreased chlorine dosage and contact time. The factors yet recorded that might affect the rate or amount of THMs creation are; exposure time, $\mathrm{pH}$, temperature, chlorine $\left(\mathrm{Cl}_{2}\right)$ concentration, predecessor concentration, type of predecessor, and inorganic parameters concentration such as ammonia $\left(\mathrm{NH}_{3}\right)$ or bromide $\left(\mathrm{Br}^{-1}\right)$ ion (Kamei and Sakamoto, 2010).

It is worthy to mention that there was an increase in the formation of brominated THMs when the chlorine dosage was high (Figs. 2 - 6), which may be related to the presence of bromide ions in chlorinated water (Sylvia et al., 2000). Many researchers have noted that the existence of bromide raises the THMs yield (Spyros, 2000 and Imo et al., 2007). The character of the bromide ion in the creation of THMs is sentient. In the absence of bromide in the raw water, the three brominated THMs are not created (Aizawa et al., 1989 and Imo et al., 2007). On the other hand the decrease in brominated THMs compounds after lowering the disinfectant ratio may be related to low chlorine dosage. Hypobromous acid ( $\mathrm{HOBr}$ ) is produced by oxidation of 
bromide ion throughout chlorination, which reacts more easily with organic predecessors than chlorine, creating brominated THMs (Singer and Chang, 1989, Chowdhury and Champagne, 2008).

According to the obtained results, scales of THMs are predominantly lower in surface water treated with $4 \mathrm{mg} / \mathrm{L}$ rather than originating from surface water treated with $5 \mathrm{mg} / \mathrm{L}$. The overall concentration of trihalomethanes (THMs) and the creation of discrete THM kinds in chlorinated water powerfully based on the constituents of the raw water, on operational items during water treatment and on the remaining chlorine $\left(\mathrm{Cl}_{2}\right)$ in the network systems (Golfinopoulos, 2000 and Duong et al., 2003). Mainly, low chlorine $\left(\mathrm{Cl}_{2}\right)$ dose and bromide concentration in water presuming lower inorganic predecessors to react with organic carbons in the water, even though furthermore, types of organic material in water such as, fulvic and humic acids performed a paramount function in defining THM creation (Hong et al., 2007).

The experimental results presented in Figures (2-6) also indicated strong correlations between the applied chlorine dosage, disinfection by- products formation and temperature for all of the water samples; that when the chlorine dosage decreased from 5 to $4 \mathrm{mg} \mathrm{l}^{-1}$, the formation of the disinfection byproducts decreased significantly. This decrease in disinfection by-products creation is directly proportional to decreasing in temperature (Chowdhury and Champagne, 2008). The temperature has also been seen to influence THMs creation in drinking water. Stevens et al. (1976) conducted experiments at three unlike temperatures $\left(3,25\right.$ and $\left.40{ }^{\circ} \mathrm{C}\right)$, at neutral $\mathrm{pH}$ and chlorine portion $10 \mathrm{mg} \mathrm{L}^{-1}$ bring to bear Ohio River water from the Cincinnati water treatment plant. The creation of THMs was set up to be $1.5-2$ times higher at each level of temperature variation. The rise in THMs creation per $10{ }^{\circ} \mathrm{C}$ increase in temperature has been predestined to range between 25-50\% (Bruce and Gary, 1983). El-Shahat et al. (2001) and Hellur-Grossman et al. (2001) announced lower THMs creation during winter months than during summer months, at higher summer temperatures, reaction rates increased yielding a higher rate of THMs creation.

An important point should be taken into consideration that the decrease in chlorine dosage did not affect disinfection process which emphasized by the presence of free chlorine at the end of the distribution system. The free chlorine for all the water samples was ranged from 2 to $1.5 \mathrm{mg} \mathrm{L}^{-1}$ and found to be higher than the level $\left(0.2 \mathrm{mg} \mathrm{L}^{-1}\right)$ sufficient for the microbial inactivation (USEPA, 2006; Derya et al., 2008 and Lee et al., 2010). Bacteriological analysis results for all samples from the plant outlet and its distribution system was shown in Figures (6-11), the data indicated that all samples had no detectable coliform, fecal coliform or fecal streptococcus bacteria after treatment. The absence of these bacteria ensures that the water has been disinfected properly. For example, the highest bacteriological count incubated at 35 and $22{ }^{\circ} \mathrm{C}$ for the plant outlet was 9 and $7 \mathrm{CFU} \mathrm{ml}{ }^{-1}$ for chlorine dosage of 5 and $4 \mathrm{mg}$ $\mathrm{L}^{-1}$ respectively, which did not exceed the recorded maximum value for the drinking water $\left(50 \mathrm{CFU} \mathrm{ml}^{-1}\right.$ ), in the decision of the Egyptian minister of health (No. 458 for 2007). Concerning the distribution system, the highest bacterial count incubated at 35 ${ }^{\circ} \mathrm{C}$ and $22{ }^{\circ} \mathrm{C}$ for El-Konoz site (beginning of the distribution system) were 6 and 5 $\mathrm{CFU} \mathrm{m}{ }^{-1}$ for chlorine dosages of 5 and $4 \mathrm{mg} \mathrm{L}^{-1}$ respectively. Likewise, at the edge of the networks (El-Manna site), the highest bacterial counts at 35 and $22{ }^{\circ} \mathrm{C}$ for a chlorine dosage of 5 and $4 \mathrm{mg} \mathrm{L}^{-1}$ were 4 and $16 \mathrm{CFU} \mathrm{ml}^{-1}$ respectively. Consequently, all these results to ensure completion of the disinfection process. (Frederik et al. 2008) reported that the main targets of drinking water treatment (from a microbiological view) are to confirm the obscurity of any pathogenic bacteria in the 
treated product and to boundary any ultimate re-growth during the distribution of the water. For this purpose, treatment systems often make use of numerous healthy barriers (e.g., ozone utilization, pre-disinfection, membrane system filtration or ultra violet (UV) disinfection during treatment, while in several countries disinfection residuals (e.g., chlorine) are added to the water before networks (Urs von, 2003).

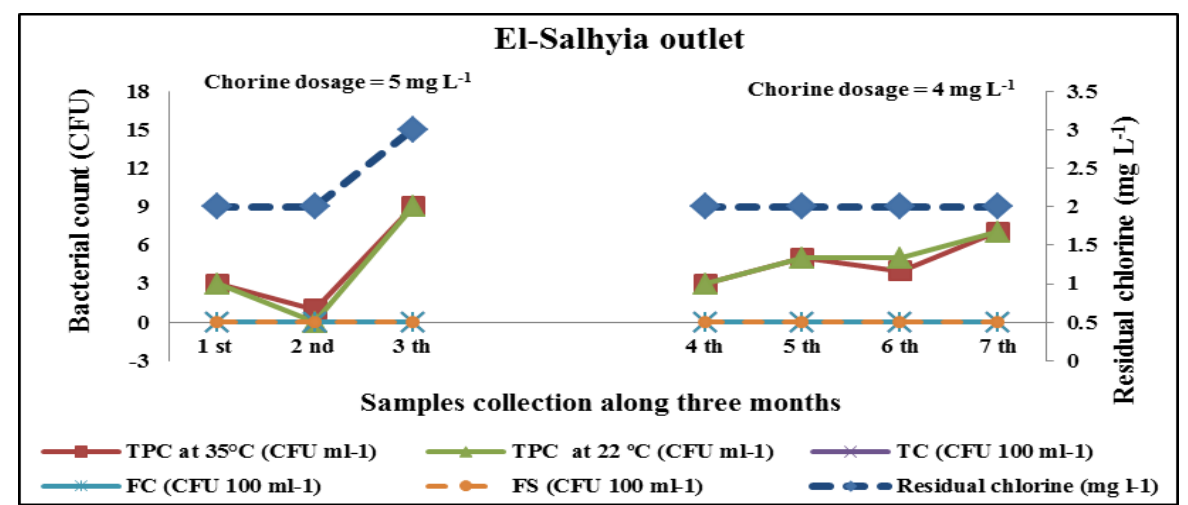

Fig. 7: Effect of two doses of chlorine on bacterial count and residual chlorine in water samples from E-Salhyia plant outlet.

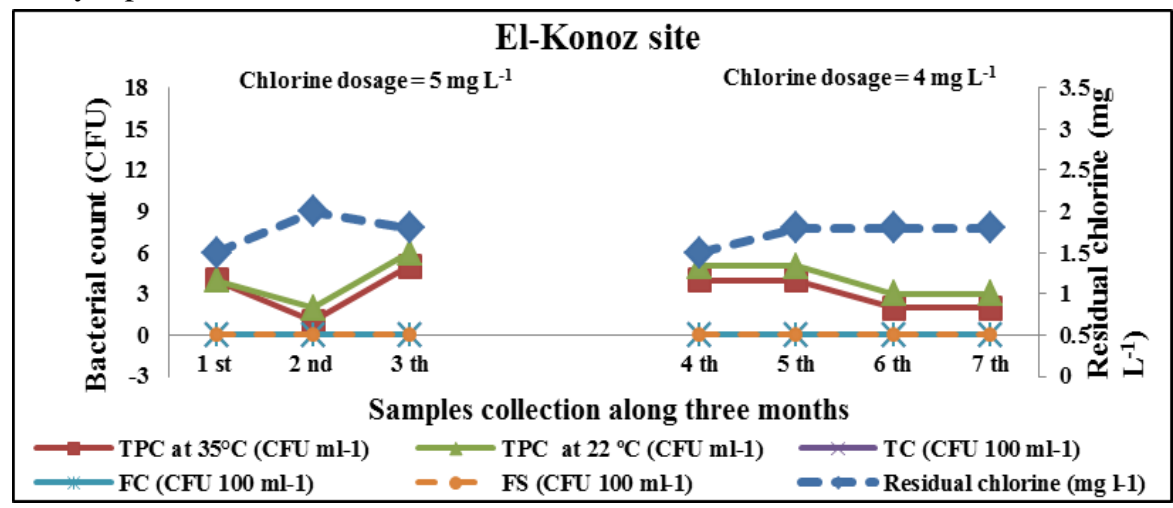

Fig. 8: Effect of two doses of chlorine on bacterial count and residual chlorine in water samples from the first site of the distribution system (El-Konoz site).

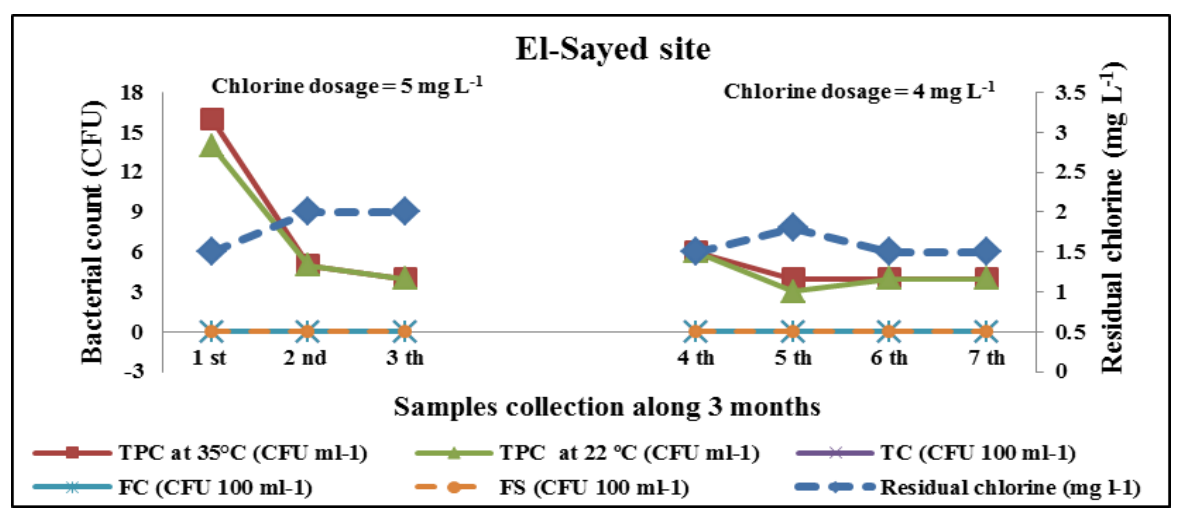

Fig. 9: Effect of two doses of chlorine on bacterial count and residual chlorine in water samples from the second site of the distribution system (El-Sayed site). 


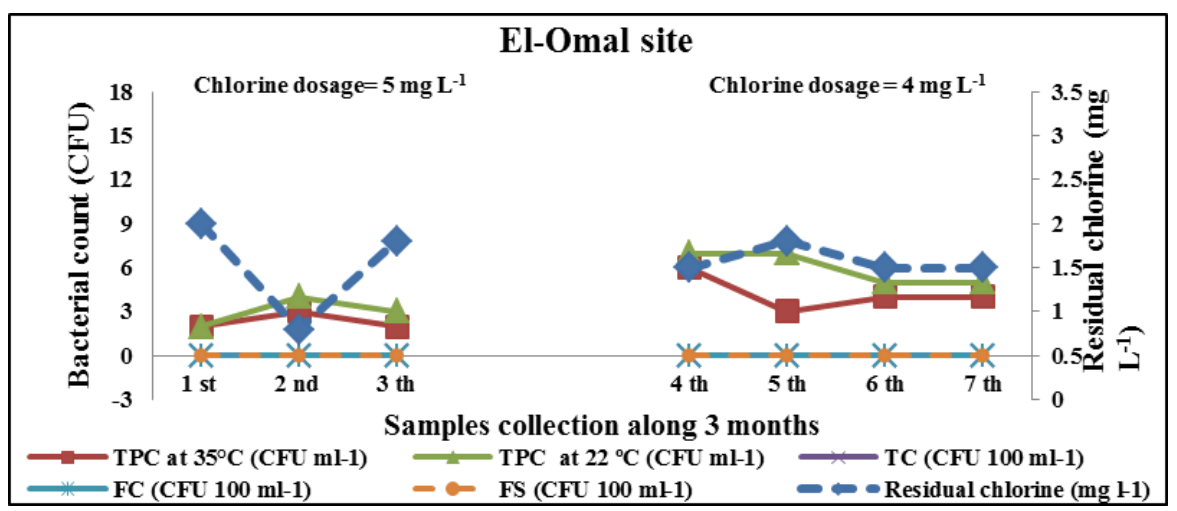

Fig. 10: Effect of two doses of chlorine on bacterial count and residual chlorine in the water samples from the third site of the distribution system (El-Omal site).

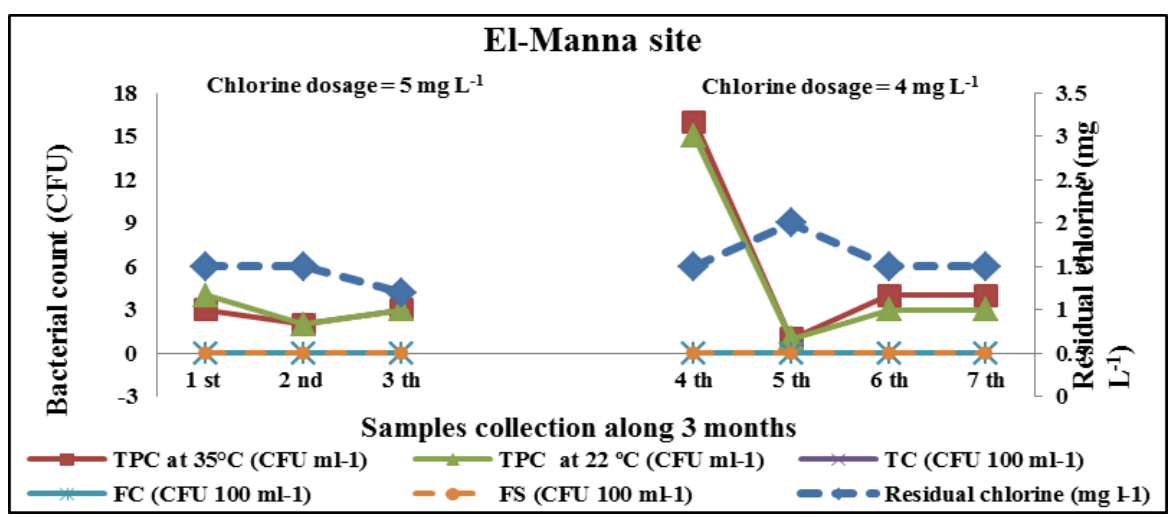

Fig. 11: Effect of two doses of chlorine on bacterial count and residual chlorine in water samples from the fourth site of the distribution system (El-Manna site).

\section{CONCLUSION}

Taking all the finding together, it is suggested that using of low and most suitable dosage of chlorine decrease disinfection by-products formation with respect to the active disinfection process. It is postulated the addition of higher concentration of chlorine fulfilled in a rise of THM predecessors in the water, which led to a congruous higher THM creation potential than would be predicted in water treated with low doses of chlorine. Therefore, it is recommended to optimize the dose of chlorine to be adequate for the killing of water- borne microorganisms and to reduce the high risk from disinfection by-product formation, in addition to reducing the environmental hazards of excess chlorine in the water

\section{ACKNOWLEDGEMENT}

The authors gratefully acknowledge the chemist Neama A. Abou El-Hagag from Central lab, Qena Company for water \& wastewater for good participating in this search. Also, the authors are thankful to faculty of Earth Sciences, Beni-Suef University, the holding company for water \& wastewater as well as Qena and Matrouh companies for water \& wastewater. 


\section{REFERENCES}

Ahmad, M. and Husain, T. (2015). Development of Predictive Models for Disinfectant Byproducts and Filtration Technology Assessments in Small Community Water Supply Systems, Memorial University, Newfoundland Labrador-Canada.https://www.mun.ca/harriscentre/reports/TahirHusainFinal. pdf.

Aizawa, T.; Magara Y. and Musashi M. (1989). Effects of bromide ion THMs formation in water, Water Resour. Aqua. Journal, 38: 165-175.

Aleksandra Szczuka; Kimberly M.P. Cassandra H. Erin H. Avner V. and William A.M. (2017). Regulated and unregulated halogenated disinfection byproduct formation from chlorination of saline groundwater, Water Res., 122: 633-644.

Anastasia, D. Nikolaou, and Themistokles, D.T. (2001). The role of natural organic matter during formation of chlorination by-products: a review, Acta Hydrochim Hydrobiol. Journal, 29: 63-67.

APHA AWWA and WEF (2005). Standard methods for examination of water and waste water, $21 \mathrm{st}$ ed. American public health association, Washington, D.C.

Bruce, A. Engerholm and Gary L. A., (1983). A predictive model for chloroform formation from humic acid, JAWWA, 75(8): 418-423.

Chowdhury Shakhawat and Champagne P. (2008). An investigation on parameters for modeling THMs Formation, Global Nest Journal 1: 80-91.

Derya Baytak; Aysun S., Fikret I., and Sait C.s. (2008). Seasonal variation in drinking water concentrations of disinfection by-products in IZMIR and associated human health risks, Sci. Total Environ Journal, 407: 286-296. drinking water distribution systems for human health risk mitigation: A

El-Shahat M.Fathy.; Abdel-Halim S.H. and Hassan G. A. (2001). Factors influencing the formation of trihalomethanes in drinking water treatment plants. Bull. Environ. Contam, Toxicol. Journal, 67: 549- 553.

Frederik Hammes; Michael, B. Yingying W., Marius V., Oliver, K., and Thomas, E. (2008). Flow-cytometric total bacterial cell counts as a descriptive microbiological parameter for drinking water treatment processes, Water Res. Journal, 42: 269-277.

Freeman, L.E.B.; Cantor, K.P., Baris, D., Nuckols, J.R., Johnson, A., Colt, J.S., Schwenn, M., Ward, M.H., Lubin, J.H., and Waddell, R. (2017). Bladder cancer and water disinfection by-product exposures through multiple routes: a population-based caseecontrol study (new England, USA), Environ. Health Perspect. 67010, 1.

Haroon R. Mian; Guangji Hu Kasun Hewage, Manuel J.Rodriguez, and RehanSadiq (2018). Prioritization of unregulated disinfection by-products in drinking water distribution systems for human health risk mitigation: A critical review, Water Research, 147; 112-131.

Hellur-G. L.; Manka J., Lamoni-Relis B., and Rebhun M. (2001). THM, haloacetic acids and other organic DBPs formation in disinfect ion of bromide rich Sea of Galilee (Lake Kinneret) water, Water Science and Technology: Water Supply Journal, 1(2): 259-266.

Hong H.C.; Liang Y., Han B.P., Mazumder A., and Wong M.H. (2007). Modeling of trihalomethane (THM) formation via chlorination of the water from Dongjiang River (source water for Hong Kong's drinking water), Science of the Total Environment Journal, 385: 48-54.

Hong, A. Dung; Michael B., Minh H.H., Viet, P. H., Hervé G., Walter G., and Urs von G., (2003). Trihalomethane formation by chlorination of ammonium- and 
bromide-containing groundwater in water supplies of Hanoi Vietnam, Water Res. Journal, 37: 3242-3252.

Imo T.S.; Oomori T., Toshihiko M. and Tamaki F. (2007) .The comparative study of trihalomethanes in drinking water, Int. J. Environ. Sci. Tech, 4 (4): 421-426.

IPCS (2000). International Program on Chemical Safety; Disinfectants and disinfectant by products, Environmental Health Criteria 216.

Jin Lee; K.wang, and T.H. Kyung, D.Z (2009). Characteristics of trihalomethane (THM) production and associated health risk assessment in swimming pool waters treated with different disinfection methods, Science of the total environment Journal, 407 (209): 1990-1997.

Jinsik Sohn; Gary, A. Jaeweon, C. Yonghun, L. and Yeomin, Y. (2004). Disinfectant decay and disinfection by products formation model development: chlorination and ozonation by-products, Water Research Journal 38: 2461-2478.

Kamei T., and Sakamoto T. (2010). Prediction of total organic halogen (TOX), Trihalomethanes (THMs) formation and residual chlorine decay by sequential first-order parallel Rreaction model, Univ. Bull. Chiba Inst, Sci. J., 3: 107121.

Kruger K.C.C. (2007). Formation and novel sensing of trihalomethanes in drinking water, Msc thesis, Arizona State University 1-107.

Law and Regulations, United States Environmental Protection Agency, https://www.epa.gov/laws-regulations/regulations, (Accessed 22 June 2017).

Li, X. and Mitch, W.A. (2018). Drinking water disinfection byproducts (DBPs) and Philip C. (2017). A historical review of the benefits and hypothetical risks o disinfecting drinking water by chlorination, J. Environ. Ecol. 8 (1),73e151.

Philip, C.Singer, and Sheng-der,C. (1989). Research Report: Impact of ozone on the removal of particles, TOC and THM precursors, AWWA Research Foundation, Denver, CO.

Spyros, K. Golfinopoulos (2000). The occurrence of trihalomethanes in the drinking water in Greece, Chemosphere, 41: 1761-1767.

Spyros, K. Golfinopoulos and Anastasia, D. N. (2005). Formation of DBPs in the drinking water of Athens, Greece: a ten-year study, Global Nest Journal,7 (1): 106-118.

Steve, E. Hrudey; Lorraine C. B.r, Andrew R. H., Stuart W. K., Dominique S. M., Lee M., Philip C. S., and Benjamin D. S. (2015). Evaluating evidence for association of human bladder cancer with drinking-water chlorination disinfection by products, J. Toxicol. Environ Health, Pt. B 18 (5):213-241.

Stevens A.A.; Slocum C.J., Seeger D.R., and Robeck C.B. (1976). Measurement of THM and precursor concentration changes, JAWWA, 68: 546-554.

Susan, D Richardson; Jane E. S. and Glenn R. (2002). Disinfection byproducts: the next generation, Environ. Sci. Technol. Journal, 36 (9): 198-205.

Sylvia E. Barrett; Stuart W. K. and Gary L. A. (2000). Natural organic matter and disinfect ion byproducts: Characterization and control in drinking water, An overview, Oxford University Press, NY.

Teng, Zeng; Michael, J. P. and William, A. M. (2016). N-Nitrosamines and halogenated disinfection byproducts in US Full Advanced Treatment trains for potable reuse, Water Res., 101: 176-186.

Urs von Gunten (2003). Ozonation of drinking water. Part I. Oxidation kinetics and product formation, Water Res. Journal, 37: 1443-1467.

USEPA (2006). National primary drinking water regulations: Disinfectants and disinfection by products Final Rule; 40CFR Parts 9, 14 and 142. Federal Register Part II, 71: 387-493. 
USEPA (1995). Determination of chlorination disinfection by-products in drinking water by liquid-liquid extraction and gas chromatography with electron-capture detection. Method 551.1, Office of research and development, Cincinnati, Ohio 45268, USA.

USEPA, (2017a). Law and Regulations. United States Environmental Protection Agency. https://www.epa.gov/laws-regulations/regulations.

USEPA, (2017b). National Recommended Water Quality Criteria - Human Health Criteria Table, United States Environmental Protection Agency, https://www. epa.gov/wqc/national-recommended-water-quality-criteria-humanhealthcriteria- table.

USEPA, (2018). Fourth Unregulated Contaminant Monitoring Rule. https://www.epa. gov/dwucmr/fourth-unregulated-contaminant-monitoring-rule.

Walsh, M.E.; Gagnon, G.A., Alam, Z., and Andrews R.C. (2008). Biostability and disinfectant by-product formation in drinking water blended with UF-treated filter backwash water, Water Res. Journal, 42: 2135-2145.

Whitaker H., Nieuwenhuijsen M.J., Best N., Fawell J., Gowers A., and Elliot P. (2003). Description of trihalomethane levels in three UK water suppliers, J. Expo. Anal Environ Epidemiol. Journal, 13: 17-23.

Yi-Hsueh, C. and William A. M. (2017). Effect of ozonation and biological activated carbon treatment of wastewater effluents on formation of $\mathrm{N}$-nitrosamines and halogenated disinfection byproducts, Environ. Sci. Technol., 51(4): 2329-2338. 